African Crop Science Journal by African Crop Science Society is licensed under a Creative Commons Attribution 3.0 Uganda License. Based on a work at www.ajol.info/ and www.bioline.org.br/cs DOI: http://dx.doi.org/10.4314/acsj.v24i3.8

\title{
EFFECT OF TEMPORARY DROUGHT AT DIFFERENT GROWTH STAGES ON SNAP BEAN POD QUALITY AND YIELD
}

\author{
H.M. BESHIR ${ }^{1,2}$, R. BUECKERT ${ }^{1}$ and B. TAR'AN ${ }^{1}$ \\ ${ }^{1}$ Department of Plant Sciences, University of Saskatchewan, 51 Campus Drive, Saskatoon, SK, \\ Canada, S7N 5A8 \\ ${ }^{2}$ School of Plant and Horticultural Sciences, Hawassa University, Hawassa, Ethiopia \\ Corresponding author: bunyamin.taran@usask.ca
}

(Received 2 October, 2015; accepted 10 June, 2016)

\begin{abstract}
High quality snap bean (Phaseolus vulgaris L.) can be produced under rain-fed conditions, provided that adequate moisture is available. However, drought may occur at any stage of growth of snap bean. The objective of this study was to evaluate the effect of drought stress at different growth stages on pod physical quality and nutrient concentrations. An experiment was conducted at the Horticulture Greenhouse, Hawassa University in Ethiopia. Drought stress (50\% of field capacity [FC]) was applied at the unfolding of the fourth trifoliate leaf, flowering and pod formation, against a control with no drought stress. The drought stress treatments and eight cultivars were arranged as a factorial experiment in a completely randomised design, with three replications. Drought stress $(50 \%$ FC) during reproductive stages significantly $(\mathrm{P}<0.05)$ reduced pod texture, appearance, and pod curvature. Drought stress increased protein and zinc concentrations by 41 and 15\%, respectively; but reduced iron concentration by $15 \%$ in snap bean pods. All the tested cultivars had relatively similar responses to drought stress.
\end{abstract}

Key Words: Field capacity, nutrient concentration, Phaseolus vulgaris

\section{RÉSUMÉ}

Une bonne qualité du haricot (Phaseolus vulgaris L.) peut être produit en saisons pluvieuses, lorsque le taux d'humidité est adequate. Neanmoins, la sécheresse peut advenir à n'importe quell stade de développement du haricot. L'objectif de cette étude était d'évaluer l'effet de la sécheresse á different stades de développement sur l'aspect extérieur de la gousse et la concentration en éléments nutritifs du haricot. Une experimentation a été conduite dans les serres à l'Université de Hawassa en Ethiopie. Une sécheresse artificielle (50\% de capacité au champ) a été appliquée aux stades de quatrième feuille trifoliée, de floraison et de formation de gousses chez le haricot. Un traitement témoin consistait à arroser les plantes convenablement. La séchéresse artificielle et huit accessions de haricot ont été arranges dans un dispositif complètement aléatoire, avec trois répétitions. La sécheresse artificielle $(50 \%$ CC) Durant les périodes végétatives ont causé une réduction significative $(\mathrm{P}<0.05)$ de la texture des gousses, leur apparence et leur courbure. La sécheresse arttificielle a cause une augmentation des concentrations en proteins et en zinc, respectivement de 41 et $15 \%$; mais une réduction de $15 \%$ de la concentration en fer dans la gousse du haricot. Toutes les accessions testées se sont comportées de façon relativement similaire face à la sécheresse.

Mots Clés: Capacité au champ, taux de nutriments, Phaseolus vulgaris 


\section{INTRODUCTION}

Inadequate and variable water supply has a negative effect on crop production across different climatic regions. The problem is more prominent in tropical and subtropical semiarid and arid climates, in which water losses through evaporation and evapotranspiration are high throughout the year (Perry and Perry, 1989). Management of water resources is a global challenge compared to other environmental factors (Mavi and Tupper, 2004).

Drought, which can occur at any stage during plant growth, reduces pod yield and pod quality of snap bean. Drought reduces the number of flowers, pod setting and leaf area in bean by 51 , 63 and $60 \%$, respectively (Barrios et al., 2005). Flowering and post-flowering are the most sensitive growth stages to drought in common bean (Calvache et al., 1997; Manjeru et al., 2007). Gunton and Evenson (1980) demonstrated that drought stress during pre-flowering and flowering stages reduces seed yield by 28 and $24 \%$, respectively, and lowers seed quality of common bean. Cakir (2004) reported that drought stress at all growth stages reduces yield and yield components in corn, but the effect was worst when drought occurred during reproductive stages. Ghassemi-Golezani et al. (2009) reported that drought stress at any growth stage reduced grain yield of faba bean.

In addition to pod yield and pod physical qualities, nutrient concentration in green pods of snap bean could also be affected by drought stress. However, reports are contradictory on the effect of drought stress on nutrient concentrations, such as protein, zinc and iron in seeds of common bean (De Mejia et al., 2003; Ghanbari et al., 2013; Ghanbari et al., 2015). Most studies mainly focused on the effect of drought stress on nutrient concentrations in dry seeds of common bean. However, information is lacking on the effect of drought stress on nutrient concentrations in green pods of snap bean. There is also limited information on the effect of drought stress during specific developmental stage on pod physical qualities in snap bean such as pod curvature, texture and appearance.

The objective of this study was to evaluate the effect of drought stress at different growth stages on physical pod qualities of snap bean and nutrient richness in snap bean pods.

\section{MATERIALS AND METHODS}

The experiment was conducted twice; the first from September to November 2012, and the second from October to December 2013 at the Horticulture greenhouse, Hawassa University, Hawassa, Ethiopia. The physicochemical properties of the soil are presented in Table 1. Inorganic $\mathrm{N}$ fertiliser as urea at the rate of $100 \mathrm{mg}$ $\mathrm{kg}^{-1}$ dry soil was mixed with the soil at the time of seeding. The daily average temperature and relative humidity in the greenhouse were automatically controlled and were kept at $24{ }^{\circ} \mathrm{C}$ and $65 \%$, respectively. The soil used in the experiment was obtained from the Research and Farm Centre at Hawassa University.

The moisture content at field capacity (FC) of the soil was determined gravimetrically as described by Reynolds (1970). Drought stress

TABLE 1. The physicochemical characteristics of the experimental soil

\begin{tabular}{|c|c|}
\hline Profile code & Concentrations \\
\hline Sand $(\%)$ & 51.69 \\
\hline Silt $(\%)$ & 30.20 \\
\hline Clay (\%) & 18.12 \\
\hline Texture class $^{\dagger}$ & Loam \\
\hline $\mathrm{pH}-\mathrm{H}_{2} \mathrm{O}(1: 2.5)^{\ddagger}$ & 6.10 \\
\hline $\mathrm{pH}-\mathrm{KCl}^{2}(1: 2.5)^{\ddagger}$ & 5.22 \\
\hline $\mathrm{EC}\left(\mathrm{ms} \mathrm{cm}^{-1}\right)(1: 2.5)$ & 0.17 \\
\hline Exch.Na (cmolc kg-1 soil) * & 0.60 \\
\hline Exch.K $\mathrm{K}^{+}\left(\mathrm{cmolc} \mathrm{kg}^{-1}\right.$ soil) ${ }^{*}$ & 2.41 \\
\hline Exch.Ca ${ }^{2+}\left(\mathrm{cmolc} \mathrm{kg}^{-1}\right.$ soil) ${ }^{*}$ & 12.93 \\
\hline Exch. $\mathrm{Mg}^{2+}\left(\mathrm{cmolc} \mathrm{kg}^{-1} \text { soill }\right)^{*}$ & 8.08 \\
\hline sum of cations (cmolc kg-1 soil) & 36.01 \\
\hline CEC (cmolc kg ${ }^{-1}$ soil) & 24.01 \\
\hline Organic carbon $(\%)^{* *}$ & 1.55 \\
\hline Nitrogen $(\%)^{t+}$ & 0.10 \\
\hline Available $\mathrm{P}\left(\mathrm{mg} \mathrm{P}_{2} \mathrm{O}_{5} \mathrm{~kg}^{-1}\right.$ soil) \# & 91.68 \\
\hline Available K (mg K $\mathrm{O} \mathrm{kg}^{-1}$ soil) * & 973.64 \\
\hline Exchangeable sodium \% (ESP) * & 1.66 \\
\hline $\mathrm{Cu}$ (mg kg-1 soil) & 0.39 \\
\hline $\mathrm{Fe}^{3+}\left(\mathrm{mg} \mathrm{kg}^{-1}\right.$ soil) & 25.93 \\
\hline $\mathrm{Mn}^{2+}\left(\mathrm{mg} \mathrm{kg}^{-1}\right.$ soil $)$ & 27.03 \\
\hline $\mathrm{Zn}^{+}\left(\mathrm{mg} \mathrm{kg}^{-1}\right.$ soil) & 3.78 \\
\hline
\end{tabular}

Methods: ${ }^{\dagger}$ Hydrometer; ${ }^{\ddagger}$ Acid neutralization; ${ }^{*}$ Ammonium acetate; "Olsen; **Walkley and Black; " ${ }^{\dagger}$ Kjeldahl; \# Instrumental 
was set at $50 \% \mathrm{FC}$, as this was found to be sufficient to cause stress in the snap bean cultivars based on the results of our preliminary experiment (Beshir, 2015).

Pot volume was 7 litres. Each pot was filled with three kilograms of dry soil. The moisture level of the soil in each pot was maintained above $90 \%$ FC, until the drought treatment was applied. In order to impose temporary drought stress at each specific growth stage, the moisture level was maintained at $50 \% \mathrm{FC}$ for 5 days by weighing pots on a digital balance, and adding the deficit water when the moisture content decreased below $50 \%$ of FC each day. Because cultivars had different days to maturity, drought treatments were applied at V4.4, R6 and $\mathrm{R} 7$ respective developmental stages. After each drought treatment, watering was resumed and maintained above $90 \% \mathrm{FC}$, until the end of harvest period. Harvesting ended 53-57 days after planting depending on the cultivar. Tap water was used for watering during the entire experiment.

Temporary drought stress was applied at each of the three different developmental stages: (i) at the fourth trifoliate leaf stage i.e. when the fourth trifoliate leaf in the stem of $50 \%$ of the plants in a bean crop is unfolded [V4.4]; (ii) at flowering stage, i.e. when the first open flower appears on the plant or when $50 \%$ of the plants in a bean crop show this characteristic [R6]); and (iii) at pod formation stage when a plant shows the first pod with the flower's corolla hanging or detached and in a crop when $50 \%$ of the bean plants show this characteristic [R7]) as defined by CIAT (1986). A control treatment (moisture level maintained above $90 \%$ FC throughout the growing period), was included as the fourth treatment.

The four drought stress treatment was tested with eight snap bean cultivars. Six of the cultivars (Andante, Boston, Contender Blue, Lomami, Paulista and Volta) were commercial cultivars currently grown by snap bean producers in Ethiopia for export markets. The other two cultivars (Melkassa 1 and Melkassa 3) were recommended cultivars for green pod production (Lemma et al., 2008), locally developed by Melkassa Agricultural Research Centre in Ethiopia. The drought stress treatments and the cultivars were arranged factorially in a completely randomised design (CRD), with three replications.
Each treatment combination (experimental unit) consisted of four pots sown with four seeds in each pot, and thinned to two plants per pot at the primary leaf stage (V2). Other regular plant maintenance practices such as weeding and hoeing were done when necessary.

Days to maturity was calculated as the number of days from seeding to $50 \%$ pod harvest maturity (fleshy pods with small green immature seeds). The fresh weight of the pods from all the four pots of each treatment, at harvest maturity, was determined and the average yield was calculated per plant. Pod numbers per plant were determined. Dry weight of the pods was determined by drying the pods in an oven at $70^{\circ} \mathrm{C}$ for 48 hours. After cooling to room temperature, the samples were weighed using Mettler Toledo analytical balance.

At harvest maturity, pod yield was sorted into marketable pods, which were firm, bright green, and tender fleshy pods with small green immature seeds. Unmarketable pods (defective, curved and shriveled pods) were discarded. The fresh weights of marketable pods were determined and calculated as marketable pods per plant.

The length and diameter of pods, from four randomly selected sample plants (four plants from each treatment or experimental unit), were measured with a tape measure and sieve (a ruler with graduated holes on its surface), respectively. Pod diameter was determined by inserting the pod into the appropriate hole best fitting for the pod. Pod curvature was calculated by measuring the actual length of the pod and the shortest distance from the two ends of the pod. The ratio of the latter to the former shows the extent of the curvature of the pod.

Texture and appearance were scored using a visual rating scale modified from Martinez et al. (1995) and Proulx et al. (2010). Pod texture and appearance were rated by five experienced individuals in the region, who work in grading and packing commercial snap beans for export markets. The surface quality (roughness or smoothness) of the pods was expressed as pod texture. Pod texture scale consisted of : $1=$ very fine (extremely smooth surface); 2 = fine (smooth surface) 3 = reasonably fine (moderately smooth surface) 4 = coarse (rough surface); and $5=$ very coarse (very rough) surface. Pod appearance was expressed as the overall look of the pods, which 
is a combination of different expressions (finess of texture, absence of defect, straightness of pods, small and immature seeds) on the pod. Pod appearance was scored as: 1 = excellent (field fresh, bright, straight, extremely tender and firm, snaps very easily, uniform); $2=\operatorname{good}($ field fresh, bright, slightly curved, tender and firm, snap easily, slightly rippled); 3 = acceptable (moderately field fresh, moderate bright, moderate curved, tender but less firm, moderately rippled); $4=$ poor (less fresh, green but not bright, curved, bent easily not snap, rippled, some blemish on surface); 5 = rejected (dull green, very curved, does not snap, very rippled, blemish on surface, defective with disease and insect bites).

In order to determine titratable acidity (TA) and total soluble solids (TSS), snap bean pod juice was made by decorticating five snap bean pods using mortar and pestle, followed stirring by juice maker.

For TA, aliquots $(10.0 \mathrm{~g})$ of pod juice were diluted with $50 \mathrm{ml}$ distilled water. The acidity was determined by titration with $0.1 \mathrm{~N} \mathrm{NaOH}$, with pink colour as the end point. The results were converted into percentage malic acid, which is the main organic acid in snap bean (Martinez et al., 1995) using the formula of Proulx et al. (2010):

$$
\mathrm{TA}=\frac{\mathrm{ml} \mathrm{NaOH} * 0.1 \mathrm{~N} * 0.067 \mathrm{meq}}{10.0 \mathrm{~g}} \times 100
$$

Where: $\mathrm{TA}=$ titratable acidity, $\mathrm{ml}=$ millilitre, $\mathrm{NaOH}$ = Sodium hydroxide, $\mathrm{N}=$ Normal (normality of $\mathrm{NaOH})$, meq $=$ milli-equivalent $($ molecular weight of malic acid =67), $g=$ gramme (juice).

Total soluble solids of the pods were measured using a hand-held refractometer for Brix (TBT, RHB0-80, Jiangsu, China).

Total nitrogen and phosphorus in green pods of snap bean were measured by sulfuric acidhydrogen peroxide digestion, using a temperature-controlled digestion block (Watanabe and Olsen,1965; Thomas et al., 1967); followed by determination of total $\mathrm{N}$ and phosphorus concentration in the digest (Watanabe and Olsen,1965) using automated colorimetry (Technicon Instruments Corporation, New York, USA). Protein concentration was estimated by multiplying the $\mathrm{N}$ value by 6.25 (Imran et al., 2008). Zinc and iron concentrations were analysed on the novAA ${ }^{\circledR} 330$ Atomic Absorption Spectrometer, (Analytikjena, Jena, Germany) using an air/acetylene flame. Calcium and potassium concentrations were analysed using the same NovAA330 Atomic Absorption Spectrophotometer, using nitrous oxide as the oxidant for the acetylene.

The nutrient concentrations were converted into nutrient content per pod dry matter of each plant using Equation 2 below. Whereas those nutrient concentrations expressed in parts per million (ppm) were converted into nutrient content per pods of each plant using Equation 3.

Nutrient content (gramme per pods of each plant $)=$

Pod dry weight per plant $x$ Nutrient concentration (\%) 100 Equation (2)

Nutrient content (gramme per pods of each plant) $=$

Pod dry weight per plant x Nutrient concentration (ppm) 1000000

Equation (3)

Data from the two runs of this experiment were combined and analysed using PROC MIXED procedure of the SAS software Version 9.3 (SAS Institute Inc., 2012) to determine Analysis of Variance (ANOVA). A two-way ANOVA was applied to determine significant differences among cultivars and drought treatments and their interaction. Means were separated according to Fisher's Protected LSD at $\mathrm{P}<0.05$. Pearson correlation analysis was done to study correlations between pod yield and pod nutrient concentrations, and among different nutrient concentrations in pods.

\section{RESULTS}

Results of the combined analysis demonstrated no significant effect of the interactions of the drought treatments and snap bean cultivars on all parameters, therefore, only the main effects of drought treatments and cultivars are presented for each parameter. 
Pod yield and time to maturity. Total fresh yield, number of pods and days to maturity were affected by temporary drought stress at different developmental stages and cultivars (Table 2). Pod dry weight per plant was only affected by drought stress.

Temporary drought stress during all developmental stages reduced total yield. The drought, during the reproductive (R6 and R7) and vegetative stages reduced total yield by $36 \%$ and $24 \%$, respectively (Table 2 ). All cultivars had a similar pod yield, except Andante, which had a lower yield.

Even though drought stress during all developmental stages reduced the number of pods per plant, pod yield reduction was most severe at R6 (Table 2). The effect of temporary drought stress during all developmental stages was similar for pod dry matter per plant. Andante produced more pods per plant than other cultivars, Boston and Lomami. Melkassa cultivars produced lower pod numbers compared to commercial cultivars (Table 2).
Temporary drought stress at all developmental stages delayed maturity of snap bean pods and was the most pronounced when drought stress occurred at V4.4 and R7. Melkassa 1 was the latest cultivar to mature, while Andante was the earliest of all cultivars (Table 2).

Marketable yield and pod physical qualities. Temporary drought stress during different developmental stages and for different cultivars significantly $(\mathrm{P}<0.05)$ affected snap bean marketable yield, pod length, diameter, curvature, texture and appearance (Table 3). Cultivar and temporary drought stress, however, had no effect $(\mathrm{P}>0.05)$ on TSS and titratable acidity of snap bean pods.

Temporary drought stress during V4.4, R6 and R7 stages reduced marketable yield by 25,42 and $48 \%$, respectively (Table 3 ). Boston produced a higher marketable pod yield than Andante and Contender Blue. Temporary drought stress at all developmental stages reduced pod length, but pod diameter was reduced only at R6. The

TABLE 2. Effect of temporary drought stress at different developmental stages on means of total yield per plant, number of pods per plant, pod dry weight per plant and days to maturity for eight snap bean cultivars at Hawassa, Ethiopia

\begin{tabular}{lcccc}
\hline Treatment & $\begin{array}{c}\text { Total yield plant }^{-1} \\
\text { (g) }\end{array}$ & $\begin{array}{c}\text { Number of pods plant } \\
\text { (count) }\end{array}$ & $\begin{array}{c}\text { Pod dry weight plant } \\
\text { (g) }\end{array}$ & $\begin{array}{c}\text { Days to maturity } \\
\text { (days) }\end{array}$ \\
\hline Drought stress & & & & \\
Control & 35.1 & 13.9 & 2.96 & 50.7 \\
Vegetative (V4.4) & 26.7 & 11.4 & 2.09 & 53.1 \\
Flowering (R6) & 22.4 & 9.65 & 1.89 & 51.5 \\
Pod formation (R7) & 22.3 & 10.9 & 2.04 & 53.1 \\
& & & & \\
LSD (0.05) & 2.59 & 0.94 & 0.26 & \\
& & & & \\
Cultivar & & & & 51.0 \\
Andante & 21.9 & 13.6 & 2.09 & 52.8 \\
Boston & 28.9 & 13.1 & 2.30 & 51.5 \\
Contender Blue & 25.6 & 11.4 & 2.19 & 52.4 \\
Lomami & 28.0 & 12.8 & 2.32 & 53.8 \\
Melkassa 1 & 29.1 & 9.6 & 2.24 & 51.8 \\
Melkassa 3 & 26.0 & 8.0 & 2.06 & 51.9 \\
Paulista & 26.5 & 11.6 & 2.20 & 51.6 \\
Volta & 27.1 & 11.9 & 2.55 & \\
& & & & ns \\
LSD (0.05) & 3.66 & 1.33 & & \\
\hline
\end{tabular}

ns $=$ non-significant 
TABLE 3. Marketable pod yield and other parameters of different snap bean as affected by temporary drought stress at different developmental stages at Hawassa in Ethiopia

\begin{tabular}{lcccccc}
\hline Treatment & $\begin{array}{c}\text { Marketable } \\
\text { yield plant }{ }^{-1}(\mathrm{~g})\end{array}$ & $\begin{array}{c}\text { Pod length } \\
(\mathrm{mm})\end{array}$ & $\begin{array}{c}\text { Pod diameter } \\
(\mathrm{mm})\end{array}$ & Pod curvature & $\begin{array}{c}\text { Texture } \\
(1-5)^{\dagger}\end{array}$ & $\begin{array}{c}\text { Appearance } \\
(1-5)^{\ddagger}\end{array}$ \\
\hline Drought stress & & & & & & \\
Control & 32.8 & 112 & 6.48 & 0.980 & 1.54 & 1.65 \\
Vegetative (V4.4) & 24.5 & 104 & 6.45 & 0.980 & 1.56 & 1.87 \\
Flowering (R6) & 19.0 & 105 & 6.25 & 0.860 & 3.15 & 3.71 \\
Pod formation (R7) & 17.2 & 102 & 6.44 & 0.900 & 3.29 & 3.94 \\
& & & & & & \\
LSD (0.05) & 2.55 & 0.27 & 0.52 & 0.01 & 0.23 & 0.23 \\
& & & & & & \\
Cultivar & & & & & & \\
Andante & 19.8 & 95 & 5.12 & 0.940 & 2.17 & 2.46 \\
Boston & 26.2 & 106 & 6.19 & 0.936 & 2.21 & 2.42 \\
Contender Blue & 22.4 & 99 & 6.36 & 0.932 & 2.13 & 2.63 \\
Lomami & 25.1 & 105 & 6.00 & 0.933 & 2.21 & 2.50 \\
Melkassa 1 & 24.7 & 109 & 7.87 & 0.935 & 3.17 & 3.75 \\
Melkassa 3 & 22.8 & 118 & 7.13 & 0.928 & 2.70 & 3.33 \\
Paulista & 23.2 & 105 & 6.38 & 0.915 & 2.33 & 2.75 \\
Volta & 23.1 & 109 & 6.21 & 0.930 & 2.08 & 2.50 \\
& & & & & & \\
LSD (0.05) & 3.61 & 0.39 & 0.26 & 0.02 & 0.32 & 0.32 \\
\hline
\end{tabular}

+ Score ( $1=$ very fine, 2 = fine, $3=$ reasonably fine, $4=$ coarse/ rough, $5=$ very coarse/rough)

‡Score ( 1 = excellent, 2 = good, 3 = acceptable, 4 = poor, 5 = rejected $)$

longest pods were produced by Melkassa 3 and the largest pod diameter by Melkassa 1. Andante produced the shortest pods, with the smallest pod diameters (Table 3 ).

The most curved pods were produced under temporary drought stress during R6; followed by R7 (Table 3; Fig. 1). Temporary drought stress during V4.4 had no effect on the curving pods, cultivar differences were not evident for pod curvature.

Temporary drought stress during R6 and R7 stages resulted in coarse texture and poor appearance of the pods (Table 3, Fig. 1). Temporary drought stress during V4.4 had no effect on the texture of snap bean pods, but resulted in a poorer appearance of the pods. The texture and appearance of Melkassa cultivars were coarser and poorer than other commercial cultivars (Table 3 ).

Pod nutrient concentrations. Temporary drought stress significantly affected all nutrient concentrations (Tables 4 and 5). Significant differences among the cultivars were observed for protein, zinc, iron and calcium concentrations in the snap bean pods.

Temporary drought stress during all developmental stages significantly increased protein concentrations (Table 4) especially during reproductive (R6 and R7) and vegetative stages (V4.4) by 10 and 5\%, respectively. Protein concentration had high and significant negative correlations with total yield $(\mathrm{r}=-0.99)$, marketable yield $(r=-0.99)$ and iron concentration $(r=-0.98)$. In contrast, protein had high and significant positive correlations with zinc concentration $(\mathrm{r}=$ 0.98 .

Drought stress during flowering stage (R6) significantly increased phosphorus concentration in the pods. Among cultivars, Lomami produced greater protein concentration than Andante, Contender Blue and Melkassa cultivars (Table 4).

Temporary drought stress during all developmental stages increased zinc concentrations in snap bean pods (Table 4). 

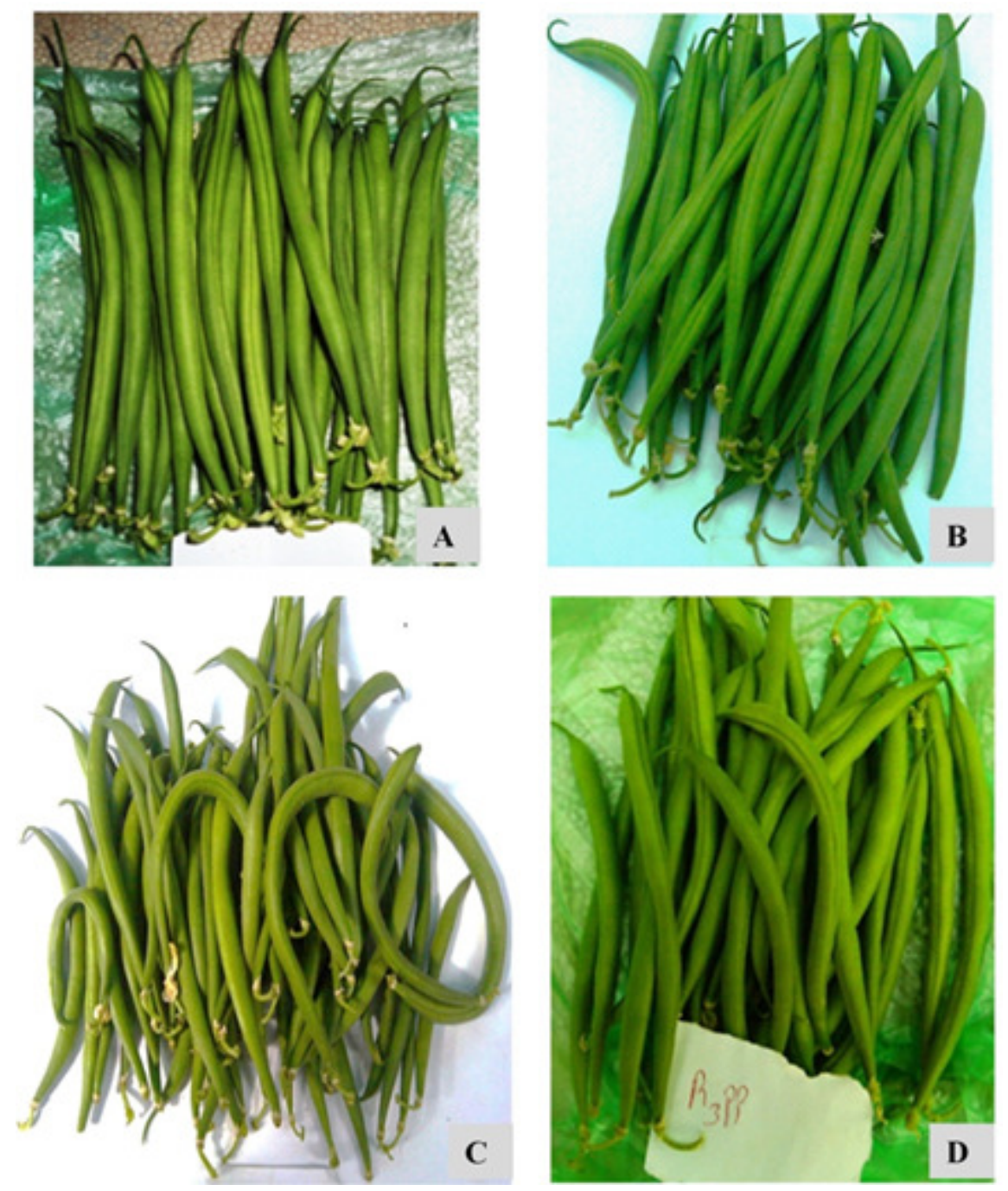

Figure 1. Effect of temporary drought stress at different developmental stages on pod quality of snap bean cv. Paulista at Hawassa, Ethiopia. (A) No drought stress, (B) Temporary drought at vegetative stage [V4.4], (C) Temporary drought at flowering [R6], and (D) Temporary drought at pod formation [R7].

Drought stress during vegetative (V4.4), flowering (R6) and pod formation (R7) stages increased zinc concentrations by 6,14 and $15 \%$, respectively. Zinc concentration had high and significant negative correlations with total yield $(\mathrm{r}=-0.96)$, marketable yield $(\mathrm{r}=-0.98)$ and iron concentration $(\mathrm{r}=-0.99)$. Among cultivars, Melkassa 1 had greater zinc concentrations than Contender Blue, Melkassa 3, Paulista and Volta under greenhouse conditions (Table 4).

Temporary drought stress during vegetative (V4.4), flowering (R6) and pod formation (R7) reduced iron concentration of snap bean pods by 7,12 and $15 \%$, respectively (Table 5 ). Severe reduction of iron was observed when drought stress occurred during the reproductive stages (R6 and R7). Iron concentration had a high and significant positive correlation with total yield ( $\mathrm{r}$ $=0.97)$ and marketable yield $(r=0.99)$. Contender Blue had a greater pod iron concentration than Andante, Lomami, Paulista and Volta (Table 5).

Temporary drought stress during V4.4 and R6 tended to increase calcium concentrations (Table 5). Andante, Boston, Paulista and Volta 
TABLE 4. Protein, phosphorus $(P)$, zinc $(\mathrm{Zn})$ concentrations and contents of snap bean pods as affected by temporary drought stress at different developmental stages and cultivars at Hawassa, Ethiopia

\begin{tabular}{|c|c|c|c|c|c|c|}
\hline Treatment & $\begin{array}{c}\text { Protein } \\
\text { concentration } \\
(\%)\end{array}$ & $\begin{array}{l}\text { Protein } \\
\text { content }{ }^{\ddagger} \\
\left(\text { mg plant }^{-1}\right)\end{array}$ & $\begin{array}{c}\mathrm{P} \\
\text { Concentration } \\
(\%)\end{array}$ & $\begin{array}{l}\text { P Content }{ }^{\ddagger} \\
\left(\text { mg plant }^{-1}\right)\end{array}$ & $\begin{array}{c}\mathrm{Zn} \\
\text { Concentration } \\
(\mathrm{ppm})\end{array}$ & $\begin{array}{l}\text { Zn Content }{ }^{\ddagger} \\
\text { Micro }\left(\text { g plant }^{-1}\right)\end{array}$ \\
\hline \multicolumn{7}{|l|}{ Drought stress } \\
\hline Control & 19.13 & 564 & 0.479 & 2.48 & 33.4 & 98.7 \\
\hline Vegetative (V4.4) & 20.19 & 422 & 0.493 & 2.52 & 35.3 & 73.2 \\
\hline Flowering (R6) & 21.05 & 394 & 0.518 & 2.54 & 37.9 & 70.3 \\
\hline Pod formation (R7) & 20.99 & 426 & 0.508 & 2.49 & 38.4 & 76.8 \\
\hline $\operatorname{LSD}(0.05)$ & 0.78 & 52.5 & 0.03 & ns & 1.8 & 9.2 \\
\hline \multicolumn{7}{|l|}{ Cultivar } \\
\hline Andante & 19.68 & 407 & 0.509 & 2.48 & $37.9 b$ & 86.1 \\
\hline Boston & 21.08 & 481 & 0.492 & 2.62 & 36.4 & 84.8 \\
\hline Contender Blue & 19.80 & 428 & 0.489 & 2.42 & 35.5 & 82.3 \\
\hline Lomami & 21.20 & 486 & 0.510 & 3.20 & 36.7 & 82.0 \\
\hline Melkassa 1 & 20.05 & 447 & 0.486 & 2.54 & 38.5 & 77.7 \\
\hline Melkassa 3 & 20.02 & 405 & 0.498 & 2.07 & 35.4 & 77.4 \\
\hline Paulista & 20.09 & 435 & 0.505 & 2.30 & 35.3 & 76.4 \\
\hline Volta & 20.78 & 521 & 0.507 & 2.45 & 34.2 & 71.4 \\
\hline $\operatorname{LSD}(0.05)$ & 1.1 & 74.2 & ns & ns & 2.56 & ns \\
\hline
\end{tabular}

‡ Nutrient content per pod dry matter of a single plant. ns = non-significant

had greater calcium concentrations in green pods compared to the other cultivars. Temporary drought stress during R6 stage increased potassium concentration of pods, but there was no significant difference among cultivars (Table 5).

With regard to nutrient content, drought stress at all developmental stages reduced protein, zinc, iron, calcium and potassium contents (Tables 4 and 5). The control treatment, which received continuous watering had the highest nutrient content compared to other treatments for all nutrients (Tables 4 and 5). Nutrient content was associated with the pod yield of snap bean (Tables 2, 4 and 5). High yielding cultivars such as Volta had higher nutrient content than the low yielding ones such as Andante (Tables 4 and 5). Protein content was decreased by 25,30 and $24 \%$ due to drought stress treatment at V4.4, R6 and R7 developmental stages, respectively (Table 4). Zinc content also decreased by 25,27 and $21 \%$ due to drought stress, at V4.4, R6 and R7 developmental stages, respectively. A similar trend was observed for other nutrient content of snap bean pods.

\section{DISCUSSION}

Drought stress at all developmental stages reduced yield and yield components of snap bean pods (Table 2). Yield reduction was most severe when drought occurred during the reproductive phases. Previous reports on common bean also found similar result (Nielsen and Nelson, 1998; Boutraa and Sanders, 2001; Molina et al., 2001).

Pods per plant was reduced when drought stress occurred during flowering (R6) (Table 2). The reduction in pod number was due to abscission of reproductive organs (flowers and pods) caused by drought (Boutraa and Sanders, 2001). Thus, flowering was the most sensitive stage for drought stress.

Drought stress during vegetative (V4.4) and pod formation (R7) severely delayed maturity of snap bean (Table 2). Delayed maturity due to drought during vegetative growth may be due to 
TABLE 5. Iron ( $\mathrm{Fe}$ ), calcium ( $\mathrm{Ca}$ ) and potassium (K) concentrations and contents of snap bean pods as affected by temporary drought stress at different developmental stages and cultivars at Hawassa, Ethiopia

\begin{tabular}{|c|c|c|c|c|c|c|}
\hline Treatment & $\begin{array}{c}\mathrm{Fe} \\
\text { Concentration } \\
(\mathrm{ppm})\end{array}$ & $\begin{array}{c}\text { Fe Content } \\
\left(\mu g \text { plant }^{-1}\right)\end{array}$ & $\begin{array}{c}\mathrm{Ca} \\
\text { Concentration } \\
(\%)\end{array}$ & $\begin{array}{c}\text { Ca Content } \\
\left(\text { mg plant }^{-1}\right)\end{array}$ & $\begin{array}{c}\mathrm{K} \\
\text { Concentration } \\
(\%)\end{array}$ & $\begin{array}{l}\text { K Content } \\
\left(\text { mg plant }^{-1}\right)\end{array}$ \\
\hline \multicolumn{7}{|l|}{ Drought stress } \\
\hline Control & 130 & 389 & 0.60 & 17.8 & 3.57 & 105.3 \\
\hline Vegetative (V4.4) & 122 & 258 & 0.63 & 13.2 & 3.67 & 76.7 \\
\hline Flowering (R6) & 114 & 216 & 0.62 & 11.8 & 3.90 & 72.7 \\
\hline Pod formation (R7) & 111 & $226 b$ & 0.57 & 11.7 & 3.57 & 72.7 \\
\hline $\operatorname{LSD}(0.05)$ & 7.3 & 39.9 & 0.04 & 1.72 & 0.12 & 8.9 \\
\hline \multicolumn{7}{|l|}{ Cultivar } \\
\hline Andante & 104 & 218 & 0.68 & 14.1 & 3.67 & 76.0 \\
\hline Boston & 128 & 298 & 0.68 & 15.7 & 3.69 & 84.4 \\
\hline Contender Blue & 133 & 299 & 0.56 & 12.2 & 3.69 & 80.5 \\
\hline Lomami & 105 & 246 & 0.56 & 13.0 & 3.77 & 87.0 \\
\hline Melkassa 1 & 130 & 299 & 0.55 & 12.6 & 3.50 & 77.0 \\
\hline Melkassa 3 & 129 & 272 & 0.57 & 11.8 & 3.63 & 73.9 \\
\hline Paulista & 115 & 260 & 0.63 & 13.8 & 3.70 & 81.0 \\
\hline Volta & 111 & 287 & 0.64 & 15.9 & 3.76 & 95.1 \\
\hline $\operatorname{LSD}(0.05)$ & 10.3 & 56.4 & 0.05 & 2.4 & ns & 12.6 \\
\hline
\end{tabular}

¥Nutrient content per pod dry matter of a single plant. ns: non-significant

low assimilation of photo-assimilate by stressed plants, which results in a slow growth rate (Boonjung and Fukai, 1996). Drought stress during V4.4 stage reduces leaf area and photoassimilation capacity (Hossain et al., 2015). A slight, but non-significant delay in maturity of common bean under drought stress at flowering and pod development was previously reported in United Kingdom by Boutraa and Sanders (2001). Delayed maturity due to drought stress was also reported in rice (Ndjiondjop et al., 2010), sorghum and maize (Blum, 1996).

In contrast, Rosales-Serna et al. (2004) reported that terminal drought accelerated maturity of common beans under field conditions in Mexico. The short duration of drought in the current experiment may have checked the plant development. Resuming the normal watering after temporary drought stress may have helped plants to continue growth and development, a condition that is a bit different from terminal drought, which usually occurs in the field for an extended period of time. Under terminal stress in the field, drought duration is usually sufficient to cease the developmental process and accelerate maturity. Due to the inconsistency in the reports thus far, the mechanism for delayed maturity due to drought stress needs further studies.

Yield and yield component differences among cultivars were mainly associated with pod size and plant size (Table 2). Andante which had small pod diameter and length also had lower yield than all other cultivars. Both pod size and number determined yield of cultivars. Production of more pods may not necessarily lead to higher yield because fewer pods of larger size may result in greater yield than numerous pods of smaller size. This is reflected in Andante which had lower yield due to small pod size and in Melkassa 1 which had larger size pods but less in number. These two cultivars also contrasted in plant size and days to maturity, with Andante being smaller and earlier in maturing than Melkassa 1.

In addition to the direct effect on yield, temporary drought also indirectly affected marketable yield (Table 3 ) by reducing the 
appearance of pods through curved, malformed and undeveloped pods, which were not marketable (Fig. 1). Temporary drought stress during V4.4 also reduced marketable yield, but the relative difference with control was small. This indicates that temporary drought at V4.4 stage affects marketable yield but only by slightly reducing pod appearance (Fig. 1).

Temporary drought stress in all developmental stages reduced pod length (Table 3 ). The most curved pods resulted from drought stress during flowering (R6). Temporary drought stress during reproductive stages (R6 and R7) resulted in pods with rough texture and poor appearance. Texture and appearance of pods depend on smoothness, uniformity and overall look of the pods in the absence of disease, insect damage and other defects. Drought stress resulted in deformed, curved, rough surface pods, and poor in quality. This is the first report on the extent of curving of snap bean pods due to drought stress, particularly at flowering stage (Table 3 ).

Temporary drought stress during all developmental stages increased protein and zinc concentrations, but decreased iron concentration in the pods (Tables 4 and 5). Iron concentration was negatively correlated with protein $(r=-0.98)$ and zinc $(r=-0.99)$ in response to a short drought stress. Increased or decreased levels of protein in response to drought stress depend on plant species and organ (Sharma and Dubey, 2011). Drought stress increased protein concentrations in chickpea shoot (Rai et al., 1983), the whole barley plant (Bole and Pittman, 1978), in tomato leaves (Chao et al., 1999), and in the alfalfa shoot (Aranjuelo et al., 2011). However, levels of protein were reduced in immature and mature pods of broad bean (Ouzounidou et al., 2014), leaves of common bean (Lazcano-Ferrat and Lovatt, 1999), the wheat plant (Kulshrestha et al., 1987) and in shoots and roots of rice (Sharma and Dubey, 2005).

Reports are contradictory for common bean seed protein concentration in response to drought stress. According to De Mejia et al. (2003) common bean seed protein concentration increased in response to drought. In contrast, Ghanbari et al. (2013) reported a decrease seed protein concentration under drought stress. Ghanbari et al. (2015) reported a trend of increased protein accumulation in developing seeds of common bean, but significantly reduced protein concentration at final seed development. Previous reports indicated that the nitrogenous solutes and free amino acids are accumulated in plant tissue in response to moisture deficit, but soluble proteins decreased (Handa et al., 1983). The increase in protein concentration in pods in our experiment may be due to higher accumulation of nitrogen solutes and free amino acids under drought stress.

Ghanbari et al. (2015) reported significant reductions in iron and zinc due to drought stress in seeds. Our results were in agreement with respect to reduced iron concentration, but contrasted with reduced zinc. Another report indicated increased zinc concentration in response to increased drought stress in alfalfa shoot (Kidambi et al., 1990). Our results also showed an increased zinc concentration in snap bean pods due to drought stress. Reports suggested that plant mineral (iron and zinc) concentrations vary with plant tissue (NchimbiMsolla and Tryphone, 2010). Zinc concentration in the pods showed similar pattern with protein concentration under temporary drought stress. This result is not unexpected because zinc plays a significant role in the activation of enzymes and protein synthesis (Cakmak et al., 1989).

Iron availability in plant tissue depends upon its availability in soil, rate of absorption by the plant root, reduction of $\mathrm{Fe}^{3+}$ to $\mathrm{Fe}^{2+}$ in the apoplast of the root, and $\mathrm{Fe}^{2+}$ uptake from the apoplast into the cytosol (Mengel, 1994). Drought stress may affect these processes and may lead to lower iron accumulation in the pods of snap bean. Iron absorption is affected by rate of water absorption and translocation into the plant system (White, 2011). A lot of iron absorption and translocation also take place late in the season (Morrissey and Guerinot, 2009), so late drought resulted in significant reduction of iron concentration in the plant tissue. However, the specific mechanism how drought stress reduce iron concentration in pods is not clear and needs further investigation.

Both phosphorus and potassium concentrations in pods showed similar patterns in response to drought (Tables 4 and 5). The concentration of both nutrients were elevated 
due to temporary drought at flowering (R6). Reports indicated that drought stress increases the concentration of potassium, but decreases that of phosphorus (Kidambi et al., 1990). However, to the best of our knowledge, there is no report on phosphorus and potassium concentrations in pods as a result of drought stress, particularly during flowering (R6).

Though drought stress increased nutrient concentrations (protein and zinc), it does not imply that drought increases nutrient content (nutrient yield). Nutrient content is highly dependent on the yield of the plant (Bauer et al., 1997). The results of our experiment also showed high dependency of nutrient content on yield. The results suggest that nutrient concentration is more reliable than nutrient content for studying physiological response of plants to temporary drought. Nutrient concentration reflects the nutrient density in plant tissues as affected by drought; while nutrient content shows the total amount of nutrients in a plant or unit area. In the current experiment, protein and zinc concentrations increased in pods under temporary drought, but the opposite was true for iron concentration. These results indicate that each nutrient has different accumulation mechanisms in response to drought. Nutrient content, on the other hand, did not show this response. Temporary drought stress decreased protein, zinc and iron, calcium and potassium contents in pods. The extent of increase or decrease in nutrient concentrations under temporary drought varied based on the developmental stages. Our results suggested that nutrient concentration is a better indicator of the plants response to drought when occurred at different developmental stages. For example, in our experiment, potassium concentration was the highest when drought occurs at flowering compared to other developmental stages; whereas, potassium content did not show these differences. Temporary drought stress reduced nutrient contents across all developmental stages.

\section{ACKNOWLEDGEMENT}

The Canadian International Food Security Research Fund (CIFSRF) of the Department of Foreign Affairs, Trade and Development and the
International Development Research Centre (IDRC) funded this research. We thank Melkassa Agricultural Research Centre and Sol Agrow PLC, both in Ethiopia, for supplying snap bean seeds. Our thanks extend to Dr. Fran Walley, Barry Goetz, Nancy Howse and Mark Cook, University of Saskatchewan, Canada, and Dr. Sheleme Beyene, Hawassa University, Ethiopia, for their technical expertise and support during the research period.

\section{REFERENCES}

Acosta-Gallegos, J. and Shibata, J.K. 1989. Effect of water stress on growth and yield ofindeterminate dry bean (Phaseolus vulgaris L.) cultivars. Field Crop Research 20: 81-93. Aranjuelo, I., Molero, G. Erice, G., Avice, J.C. and Nogués, S. 2011. Plant physiology and proteomics reveals the leaf response todrought in alfalfa (Medicago sativa L.). Journal of Experimental Botany 62: 111-123.

Barrios, A.N., Hoogenboom, G. and Nesmith, D.S. 2005. Drought stress and the distribution of vegetative and reproductive traits of a bean cultivar. Scientia Agriculturae 62: 18-22.

Bennett, J.P. 1945. Iron in leaves. Minor elements evidence and concepts on functions, deficiencies and excesses. Williams and Williams: The Ohio State University, USA. pp. 91-105.

Beshir, H.M. 2015. Improving snap bean (Phaseolus vulgaris L.) production under reduced input systems. PhD Thesis, University of Saskatchewan, Canada. 163 pp.

Bauer, G. E. Schulze, E.D. and Mund, M. 1997. Nutrient contents and concentrations in relation to growth of Picea abies and Fagus sylvatica along a European transect. Tree Physiology 17: 777-786.

Blum, A. 1996. Crop responses to drought and the interpretation of adaptation. Plant Growth Regulation 20: 135-148.

Bole, J.B.and Pittman, U.J. 1978. The effect of Fertilizer N, spring moisture, and rainfall on the yield and protein content of barley in Alberta. Proceedings 1978 Sask. Soil Crops Workshop, February 8-9, 1978.

Boonjung, H. and Fukai, S. 1996. Effects of soil water deficit at different growth stages on rice growth and yield under upland conditions. 2 . 
Phenology, biomass production and yield. Field Crops Research 48: 47-55.

Boutraa, T. and Sanders, F.E. 2001. Influence of water stress on grain yield and vegetative growth of two cultivars of bean (Phaseolus vulgaris L.). Journal of Agronomy and Crop Science 187: 251-257.

Cakir, R. 2004. Effect of water stress at different development stages on vegetative and reproductive growth of corn. Field Crops Research 89: 1-16.

Cakmak, I., Marschner, H. and Bangerth, F. 1989. Effect of Zn nutritional status on growth, protein metabolism and levels of lndole-3acetic acid and other phytohormones in bean (Phaseolus vulgaris L.). Journal of Experimental Botany 40: 405-412.

Calvache, M., Reichardt, K., Bacchp,O.O.S. and Dourado-Neto, D. 1997. Deficit irrigation at different growth stages of the common bean (Phaseolus vulgaris L., Cv. Imbabello). Scientia Agriculturae 54:1-16.

Chao, W.S., Gu, Y., Pautot, V., Bray, E. A. and Walling, L. L. 1999. Leucine aminopeptidase RNAs, proteins, and activities increase in response to water deficit, salinity, and the wound signals systemin, methyl jasmonate, and abscisic acid. Plant Physiology120: 979992.

CIAT. 1986. Centre for Agriculture in the Tropics (CIAT) Stages of Development of the common bean plant; study guide to be used as a supplement to the audiotutorial unit on the same topic. Scientific content: Fernando Fernandez; Paul Gepts, and Marceliano Lopez. English production: Oscar Arregoces, Rigoberto Hidalgo, and Adriana Correa. Cali Colombia. CIAT. 32p. (Series 04EB-09.03).

De Mejia, E.G., Martinez-Resendiz,V., CastanoTostado, E. and Loarca-Pina,G. 2003. Effect of drought on polyamine metabolizim, yield, protein content and in vitro protein digestibility in tepary (Phaseolus acutifolius) and common (Phaseolus vulgaris L.) bean seeds. Journal of the Science of Food and Agriculture 83:1022-1030.

Ghanbari, A.A., Shakiba, M.R., Toorchi, M. and Choukan, R. 2013. Nitrogen changes in the leaves and accumulation of some minerals in the seeds of red, white and chitti bean
(Phaseolus vulgaris L.) under water deficit conditions. Australian Journal of Crop Science 7:706-712.

Ghanbari, A.A., Shakiba, M.R., Toorchi, M., Choukan, R. and Pessarakli, M. 2015. Accumulation of reserve compounds in common bean seeds under drought Stress. Journal of Plant Nutrition 38: 609-623.

Ghassemi-Golezani, K., Ghanehpoor, S. and Mohammadi-Nasab, A.D. 2009. Effects of water limitation on growth and grain filling of faba bean cultivars. Journal of Food, Agriculture and Environment 7: 442-447.

Gunton, J.L. and Evenson, J.P. 1980. Moisture stress in navy bean: effect of withholding irrigation at different phenological stages on growth and yield. Irrigation Science 2: 49 58.

Handa, S., Bressan, R.A., Handa, A.K., Carpita, N.C.and Hasegawa, P.M. 1983. Solutes contributing to osmotic adjustment in cultured plant cells adapted to water stress. Plant Physiology 73: 834-843.

Hossain, M.D.M., Lam, H. and Zhang, J. 2015. Physiological response of soybean genotypes to water limiting conditions. African Crop Science Journal 23:227-238.

Imran, M., Khan, H., Hassan, S.S. and Khan, R. 2008. Physicochemical characteristics of various milk samples available in Pakistan. Journal of Zhejiang University Science 9: 546-551.

Kidambi, S.P., Matches, A.G. and Bolger, T.P. 1990. Mineral concentrations in alfalfa and sainfoin as influenced by soil moisture level. Agronomy Journal 82: 229-236.

Kulshrestha, S., Mishra, D.P. and Gupta, R.K. 1987. Changes in contents of chlorophyll, proteins and lipids in whole chloroplast membrane fractions at different leaf water potentials in drought resistant and sensitive genotype of wheat. Photosynthetica 21: 6570.

Lazcano-Ferrat, I. and Lovatt, C.J. 1999. Relationship between relative water content, nitrogen pools and growth of Phaseolus vulgaris L. and P. acufifolius A. Gray during water deficit. Crop Science 39: 467- 475.

Lemma, D., Shimelis, A., Selamawit, K. and Abyot, A. 2008. Variety development of major 
vegetables in the Rift Valley region. Ethiopian Horticulture Society. Proceedings of the First Conference, 23-24 March 2006. Addis Ababa, Ethiopia. pp. 83-89.

Manjeru, P., Madanzi,T., Makeredza,B., Nciizah, A. and Sithole, M. 2007. Effect of water stress at different growth stages on components and grain yield of common bean (Phaseolus vulgaris L.). African Crop Science Conference Proceeding 8:299-303.

Martinez, C., Ros, Periago, G.M.J., Lopez, G., Ortuno, J. and Rincon, F. 1995. Physicochemical and sensory quality criteria of green bean (Phaseolus vulgaris L.). LWTFood Science and Technology 2: 515-520.

Mavi, H. and Tupper, G.J. 2004. Agrometeorology: principles and applications of climate studies in agriculture. Haworth Press. Inc., New York, USA. pp. 376.

Mengel, K. 1994. Iron availability in plant tissuesiron chlorosis on calcareous soils. Plant and Soil 165: 275-283.

Molina, J.C., Moda-Cirino, V., Júnior, N.S.F., De Faria, R.T. and Destro, D. 2001. Response of common bean cultivars and lines to water stress. Crop Breeding and Applied Biotechnology 1: 363-372.

Morrissey, J. and Guerinot, L.G. 2009. Iron uptake and transport in plants: The good, the bad, and the ionome. Chemical Reviews 109(10): 4553 - 4567.

Nchimbi-Msolla, S.and Tryphone, G.M. 2010. The effect of the environment on iron and zinc concentrations and performance of common bean (Phaseolus vulgaris L.) genotypes. Asian Journal of Plant Science 9: 455-462.

Ndjiondjop, M.N., Cisse, F., Futakuchi, K., Lorieux, M., Manneh, B., Boccol, R. and Fatondji, B. 2010. Effect of drought on rice (Oryza spp.) genotypes according to their drought tolerance level. Second Africa Rice Congress, Bamako, Mali, 22-26 March 2010: Innovation and Partnerships to Realize Africa's Rice Potential.

Nielsen, D.C. and Nelson, N.O. 1998. Black bean sensitivity to water stress at various growth stages. Crop Science 38: 422-427.

Ouzounidou, G., Ilias, I.F., Giannakoula, A. and Theoharidou, I. 2014. Effect of water stress and $\mathrm{NaCl}$ triggered changes on yield, physiology, biochemistry of broad bean (Vicia faba) plants and on quality of harvested pods. Biologia 69: 1010-1017.

Perry, A. S.and. Perry, R. Y. 1989. Effects in arid regions. pp. 155-193. In: Bourdeau, P., Haines, J. A., Kleinand, W. and Krishna, M. C. R. (Eds.). Ecotoxicology and climate with special reference to hot and cold climates. Scope 38. IPCS Joint SYMPOSIA 9:. John Wiley \& Sons LtdP, Chichester-New YorkBrisbane-Toronto-Singapore.

Proulx, E., Yagiz, Y., Nunes, M.C.N. and Emond, J. 2010. Quality attributes limiting snap bean (Phaseolus vulgaris L.) postharvest life at chilling and non-chilling temperatures. HortScience 45: 1238-1249.

Rai, V.K., Singh, G., Thakur, P. K. and Banyal, S. 1983. Protein and amino acid relationship during water stress in relation to drought resistance. Plant Physiology and Biochemistry 10:161-167.

Reynolds, S.G. 1970. The gravimetric method of soil moisture determination: Part I a study of equipment, and methodological problems. Journal of Hydrology 11: 258-273.

Rosales-Serna, R., Kohashi-Shibata, J., AcostaGallegos, J.A., Trejo-Lo'pez, C., OrtizCereceres, J. and Kelly, J. D. 2004. Biomass distribution, maturity acceleration and yield in drought-stressed common bean cultivars. Field Crops Research 85: 203-211.

SAS Institute. 2012. The SAS system for Windows. Release 9.3. SAS Institute, Inc., Cary, NC, USA.

Sharma, P. and Dubey, R.S. 2005. Drought induces oxidative stress and enhances the activities of antioxidant enzymes in growing rice seedlings. Plant Growth Regulation 46:209221.

Sharma, P. and Dubey, R.S. 2011. Protein synthesis by plants under stressful conditions. pp. 456518. In: Pessarakli, M. (Ed.). Handbook of plant and crop stress, 3rd ed. CBC Press, Taylor \& Francis Group, New York, USA.

Thomas, R., Sheard, R.W. and Moyer, I.P. 1967. Comparison of conventional and automated procedures for nitrogen, phosphorus and potassium analysis of plant material using a single digest. Agronomy Journal 99: 240243. 
Watanabe, F. S. and Olsen, S.R. 1965. Test of an White P.J. 2011. Ion uptake mechanisms of ascorbic acid method for determining phosphorus in water and $\mathrm{NaHCO} 3$ extracts from soil. Soil Science Society of America Journal 29: 677-678. individual cells and roots: Short-distance transport. pp. 7 - 47. In: Marschner, P. (Ed.). Marschner's mineral nutrition in higher plants ( $3^{\text {rd }}$ Edition). Elsevier, UK. 